\title{
Differential activation of JAK enzymes in rheumatoid arthritis and autoimmune disorders by pro-inflammatory cytokines: potential drug targets
}

This article was published in the following Dove Press journal: International Journal of Interferon, Cytokine and Mediator Research 28 October 2010

Number of times this article has been viewed

\section{Charles J Malemud}

Arthritis Research Laboratory, Division of Rheumatic Diseases, Department of Medicine, Case Western Reserve University School of Medicine, Cleveland, OH, USA
Correspondence: Charles J Malemud Professor, Division of Rheumatic Diseases, Department of Medicine, University Hospitals Case Medical Center, Room 207, 206I Cornell Road, Cleveland, $\mathrm{OH} 44106-5076$, USA

Tel + I 2168447846

Mobile $+\mid 2165361945$

Fax + I 2168442288

Email cjm4@cwru.edu
Abstract: Although several pro-inflammatory cytokines including interleukin-6 (IL-6), IL-7, IL-12/IL-23, IL-17, IL-2, interferon, and the anti-inflammatory cytokines, IL-4/IL-13, IL-10, and IL-22, all activate the Janus kinase/signal transducers and activators of transcription (JAK/ STAT) pathway, in autoimmune disorders, a skewing of the cytokine repertoire in favor of pro-inflammatory cytokines results in amplifying the effects of pro-inflammatory cytokines. An apparent deficiency of anti-inflammatory cytokines to counterbalance the 'ramping up' of pro-inflammatory cytokine-mediated activation of JAK/STAT is also significant, while endogenous negative regulators of cytokine signaling and JAK/STAT activation may also be compromised. In addition, JAK/STAT pathway activation can result in activation of stress-activated protein/mitogen-activated protein kinase (SAP/MAPK) and phosphatidylinositol-3-kinase/ $\mathrm{Akt} / \mathrm{mammalian}$ target of rapamycin pathways that are instrumental in promoting matrix metalloproteinase gene expression, aberrant cell survival, and osteoclast differentiation. The critical role played by pro-inflammatory cytokines in differentially activating JAK/STAT and parallel signal transduction pathways resulted in the development of several cytokine/cytokine receptor neutralizing monoclonal antibodies and fusion proteins that are currently employed for treating rheumatoid arthritis, Crohn's disease, and psoriasis. Small molecule inhibitors (SMIs) that target specific JAK enzymes have led to the development of CP690550, a JAK3-specific SMI, which is the first JAK-specific SMI to reach phase III in a rheumatoid arthritis clinical trial.

Keywords: autoimmunity, cytokines, inflammation, Janus kinase, signal transducers and activators of transcription, small molecule inhibitors

\section{Introduction}

Recent and quite compelling evidence has implicated activation of the Janus kinase/ signal transducers and activators of transcription (JAK/STAT) pathway by proinflammatory and/or anti-inflammatory cytokines as a key regulatory step in the pathogenesis and progression of inflammation associated with autoimmune-mediated diseases such as rheumatoid arthritis (RA) ${ }^{1-9}$ and other autoimmune disorders, systemic lupus erythematosus (SLE) $)^{8,10}$ and Crohn's disease. ${ }^{11}$ Thus, the pro-inflammatory cytokines, interleukin-6 (IL-6), ${ }^{12-14}$ IL-7, ${ }^{15-19}$ IL-12/IL-23,,${ }^{40-23}$ IL-17, ${ }^{24-27}$ the interferon (IFN) family of proteins, ${ }^{28-31}$ as well as the macrophage-derived cytokine IL-2 ${ }^{32}$ via their interaction with specific cytokine receptors (CyRs) result in the phosphorylation (ie, activation) of JAK enzymes. ${ }^{33}$ In this regard, cytokine/CyR binding regulates a host of immune cell regulatory functions including activation of antigen-presenting 
cells such as plasmacytoid dendritic cells (DC) $)^{6,34-37}$ as well as the genesis and modulation of two T-lymphocyte subpopulations and the $T_{h} 17^{20}$ and T-regulatory $\left(T_{\text {reg }}\right)$ cell subsets, ${ }^{37-40}$ the activity of the latter T-cell subset being crucial for instituting and maintaining immune tolerance. In that regard, dysfunctional $\mathrm{T}_{\text {reg }}$ cell activity has been attributed to a breakdown in immune tolerance in $\mathrm{RA}^{37-39}$ perpetuation of immune-mediated inflammation ${ }^{40}$ and immunodysregulation, polyendocrinopathy, enteropathy, X-linked syndrome, ${ }^{41}$ a rare autoimmune disorder originating from mutations in the FoxP3 transcription factor that resulted not in defective $\mathrm{CD} 4^{+} \mathrm{CD} 25^{+} \mathrm{T}_{\text {reg }}$ cell production but rather in dysfunctional $\mathrm{T}_{\text {reg }}$ cell and effector T-cells. ${ }^{42}$

Counterbalancing the overproduction of pro-inflammatory cytokines in autoimmune-mediated inflammatory disorders should occur by activation of JAK/STAT with the anti-inflammatory cytokines IL-4, $-13,{ }^{43}-10,{ }^{44}$ and -22 (an IL-10-related cytokine). ${ }^{45}$ Of note, deficient levels of these anti-inflammatory cytokines do not appear to be responsible for blunted anti-inflammatory responses in autoimmune-mediated disorders. In actuality, higher levels of IL-13 were found in the synovial fluid of patients with RA, SLE, and Sjögren's syndrome, ${ }^{46}$ as well as in sera and synovial fluid samples from patients with psoriatic arthritis ${ }^{47}$ where the levels of IL-13 in the patient group was comparable to IL-13 levels in a control group. Additionally, no significant relationship was found to exist between IL-13 levels and antinuclear antibody titers. ${ }^{46}$ However, in RA, dysfunctional IL-10/IL-4/IL-13 could serve to blunt potential anti-inflammatory responses. Reportedly, this can occur by suppressing the synthesis of suppressor of cytokine signaling (SOCS) proteins ${ }^{48-51}$ or by the reduced production of IL-10 by $\mathrm{T}_{\text {reg }}$ cells. ${ }^{43}$ Interestingly, IL-2 was reported to enhance the synthesis of IL-10 in the T-cell line, HOZOT. ${ }^{52}$

In RA, the potential for modulating JAK/STAT terminating signals mediated by SOCS $^{48-51}$ protein tyrosine phosphatases (eg, SHP-1, -2), protein inhibitor of activated proteins, and signal transducing adaptor protein (STAM) $)^{33,53}$ must also be considered. Thus, in RA, defective regulation of these negative regulatory proteins may account for any significantly elevated levels of constitutively activated STAT proteins.

\section{Cytokine-mediated activation of the JAK/STAT pathway}

Activation of specific STAT proteins (see below) via JAK enzyme activation converts STAT proteins into potent transcription factors. ${ }^{54}$ In this conversion step, activated
STAT proteins function to up regulate the expression of pro-inflammatory and anti-inflammatory cytokine genes, ${ }^{1,33,53-55}$ modify the survival signaling pathways of activated monocytes, lymphocytes, and synoviocytes in the inflamed synovial joint ${ }^{56-60}$ and in a positive feedback loop setting down regulates JAK/STAT and cytokine signaling by activating SOCS gene expression. ${ }^{61}$ Of note, 'cross talk' between activated JAK/STAT, SAP/MAPK, and the phosphatidylinositol-3-kinase/Akt/mammalian target of rapamycin (PI3K/Akt/mTor) pathways may all be involved in promoting the survival and/or apoptosis of activated immune cells, activated synoviocytes, and chondrocytes. Thus, maintaining activated immune cell, synovial cell, and chondrocyte vitality in RA joints appears to be crucial for regulating the chronic inflammatory response $\mathrm{e}^{33,60-63}$ and for promoting chondrocyte-mediated articular cartilage repair. ${ }^{64}$

The results of recent experiments conducted in the Arthritis Research Laboratory at Case Western Reserve University shed some light on the mechanism by which inhibition of JAK enzyme activation could induce human chondrocyte apoptosis. Thus, incubating juvenile human chondrocyte macroaggregate pellet cultures ${ }^{65,66}$ with $50 \mu \mathrm{M}$ of the JAK2 tyrosine kinase inhibitor, tyrphostin (AG-490), ${ }^{67}$ induced apoptosis after $60 \mathrm{~min}$ as evidenced by the increased frequency of terminal deoxynucleotidyl transferase dUTP nick end labeling (TUNEL)-positive nuclei in $5-\mu \mathrm{m}$ histologic cross sections compared to untreated chondrocyte macroaggregate pellet cultures (unpublished data). These results suggested that induction of apoptosis by AG- $490^{67,68}$ could reflect the down regulation of JAK/STAT and MAPK pathways as was previously reported when AG-490 was incubated with an IL-6-dependent myeloma cell line. ${ }^{69}$ The down regulation of the synthesis of the gp130 signaling subunit, but not JAK2 or STAT-3, was also found in rat schwannoma RT4 cell cultures but only after treatment with recombinant human IL- $6 .{ }^{70}$

Although dampening JAK/STAT signaling is a laudable clinical goal designed to regulate chronic inflammation, inhibition of parallel SAP/MAPK ${ }^{60,62,71,72}$ and PI3K/Akt/mTor signaling pathways, ${ }^{53}$ Toll-like receptor (TLR) activation, ${ }^{62}$ and the immunoreceptor tyrosine-based activation motif pathway ${ }^{73,74}$ may also have to be considered as a way to fully ameliorate autoimmune-mediated inflammation. Nevertheless, recently, development of novel therapies with the capacity to inhibit or promote cytokine-mediated activation of the JAK/STAT pathway has been considered, which focuses on designing novel agents with the capacity to inhibit or promote cytokine-mediated activation of the 
JAK/STAT pathway for treating human myeloproliferative diseases (MPDs) ${ }^{75,76}$ and inflammatory arthritis. ${ }^{14,19,56,77,78}$ Interestingly, the $\mathrm{JAK} 2 \mathrm{~V}^{617} \mathrm{~F}$ mutation found in several lymphoproliferative disorders, which gives rise to constitutively activated STATs, was proposed as a link between B-cell dysfunction in MPDs and the B-cell hyperactivity associated with RA. ${ }^{76}$

\section{Cytokine activation of STAT proteins}

The earliest steps in the activation of JAK/STAT signaling by IFNs and other extracellular signaling molecules previously held that under basal conditions 'inactive' or unphosphorylated-STAT proteins (U-STATs) were found in the cytoplasm where they existed as free monomeric proteins. ${ }^{79}$ After the appropriate stimulation is achieved via cytokine/CyR binding, JAK enzymes are activated and the U-STAT proteins are recruited from the cytoplasmic compartment to the CyR complex using Src homology 2 (SH2) regions that are homologous between specific JAK enzymes and their respective STAT proteins.,33 This proved to be the case for IFN- $\gamma$ where the specificity of p-STAT accumulation via IFN- $\gamma$-mediated JAK1/JAK2 activation was found to reside in those interactions that occurred between $\mathrm{SH} 2$ homologous domains and specific phosphotyrosine motifs found in the JAK enzyme and STAT protein. ${ }^{79,80}$ The next step in STAT protein activation was shown to occur when phosphorylated STAT proteins (p-STATs) dissociated from the cytokine/CyR/JAK complex leading to the formation of STAT hetero/homodimers whose interaction was also stabilized via reciprocal p-STAT/SH2-phosphotyrosine motifs. The formation of p-STAT dimers facilitated their transport to the nucleus where they bound to STAT-target genes to regulate the initiation of transcription. ${ }^{33,81}$

Recent studies, however, have resulted in a paradigm shift in the interpretation of these early steps in STAT protein activation. Thus, it is now recognized along with other components of the 'revised' understanding of JAK/STAT signaling ${ }^{82}$ that U-STAT proteins exist primarily as U-STAT dimers and as high molecular mass 'statosome' complexes. Further, U-STAT proteins can also activate target genes that are distinct from those genes which are the targets for p-STAT proteins. Two examples of this phenomenon include findings that IL-6-stimulated p-STAT-3 also activated U-STAT-3 where U-STAT-3 drove the expression of both nuclear factor- $\kappa \mathrm{B}$ $(\mathrm{NF}-\kappa \mathrm{B})$-dependent and NF- $\kappa \mathrm{B}$-independent gene targets ${ }^{83}$ and the finding that IFN which drives p-STAT-1 accumulation in human mononuclear cells in vitro also resulted in a significant increase in U-STAT-1, which persisted for several days, leading to the expression of many immune-regulated genes that were distinct from those gene targets activated by $\mathrm{p}-\mathrm{STAT}-1 .{ }^{84}$

\section{Do cytokine/CyR interactions result in specific STAT protein activation?}

Seven mammalian STAT proteins, STAT-1, -2, -3, -4, STAT $5 \alpha$, STAT5 $\beta$, and STAT6 have been described, ${ }^{1}$ and specific STAT protein activation has been reported based on various cytokine/CyR interactions. For example, STAT-3 is the main STAT mediator of IL-6/IL-6/gp130 signaling, ${ }^{44,85,86}$ STAT-2 for IFN- $\alpha,{ }^{87}$ and STAT-1 and -6 for IFN- $\gamma^{88,89}$ and IL-4, ${ }^{90}$ respectively. However, STAT- 1 can also be activated by IL- $6 .{ }^{33}$ Moreover, IFN- $\alpha / \beta$ can act cooperatively with other T-cell mitogens including IL-2, $-4,-7$, and -12 to activate STAT-1 and -2, but not STAT-3. ${ }^{91}$ IL-23, a member of the IL-6/IL-12 protein family was shown to induce the formation of STAT-3/STAT-4 heterodimers and activate STAT-1, -3, -4, and $-5,{ }^{23}$ whereas IL-17 and -33 have been reported to activate STAT-3 and -5 , respectively. ${ }^{92}$

Each specific cytokine/CyR interaction is also known to produce a different downstream gene response. In that regard, studies in STAT gene knockout mice have been instructive because specific STAT gene ablation resulted in variable downstream physiological responses. ${ }^{43,93,94}$

\section{Specific gene responses initiated by cytokine/CyR interactions}

\section{The IL-6/IL-6R/gP I 30 pathway}

IL-6 belongs to a family of pleiotypic pro-inflammatory cytokines including IL-11, leukemia inhibitory factor (LIF), oncostatin $\mathrm{M}$, ciliary neurotrophic factor, epidermal growth factor, granulocyte colony-stimulating factor (G-CSF), leptin, and cardiotrophin-1 that signal through a common gp130 receptor subunit. ${ }^{52,95,96}$ The binding of IL-6 to its specific receptor (IL-6R) in conjunction with the gp130 signaling subunit initiates the activation of JAK/STAT signaling ${ }^{33,53}$ with the phosphorylation of mainly p-STAT- $3 .{ }^{95}$ In contrast, oncostatin $\mathrm{M}$ was found to mainly induce activation of JAK2/ STAT-5. ${ }^{97}$ A variety of transcriptional coactivator proteins some of which belong to a group of histone acetyltransferases but also including, CBP/p300 and CR6-initiating factor-1, were shown to improve access of p-STAT proteins to the transcription initiation complex. ${ }^{33}$ Steroid receptor coactivator-1 which at one time was considered as performing a similar function as CBP/p300 and CR6-initiating factor-1 was recently found to be dispensable for the transcriptional 
control by STAT-3, but the results of this study also confirmed the critical role of CBP/p300 in STAT-3-mediated target gene transcription. $^{98}$

Gene expression profiling microarrays have systematically cataloged those target genes which are likely to be relevant to some aspect of the pathogenesis and progression of RA and other autoimmune-mediated arthritic disorders following IL-6, oncostatin M, or LIF-mediated STAT protein activation. In that regard, Andreas et $\mathrm{al}^{99}$ recently defined 100 RA-related genes expressed by human chondrocytes after stimulation with the conditioned medium from SV40T-antigen immortalized human synovial fibroblast cultures. One of these genes, for example, Cyr61, which encodes a cysteine-rich heparin-binding protein, was known to be a STAT-3 target gene (Table 1).

\section{The IL-7/IL-7R $\alpha$ pathway}

The expression of the IL-7R $\alpha$ gene also known as CD127 is likely to be important in the pathogenesis and progression of immune-mediated arthritis because of the central role played by IL-7R in T-cell survival, the maturation of B-cells, interactions of T-cells with DCs, and as a lymphoid tissue inducer cytokine. ${ }^{15,16,18,106,107}$ Additionally, suppressed activity of the pro-apoptosis proteins $\mathrm{Bad}$ and $\mathrm{Bim}^{108}$ and the levels of antiapoptosis proteins $\mathrm{Bcl}-2$ and $\mathrm{Bax}^{109}$ have been implicated in activation of the IL-7/IL-7R regulatory pathway which in all likelihood is a contributor to defective apoptosis exhibited by activated T-cells in RA. ${ }^{57}$ Also critical to this expanded understanding of the role of IL-7/IL-7R $\alpha$-mediated signaling in RA were analyses showing elevated levels of IL-7 in RA synovial fluid. ${ }^{110}$ Additionally, the F759 mutation in gp130/IL-6R subunit resulted in elevated levels of IL-7 and activated STAT-3, ${ }^{111}$ suggesting a strong correlation between defective gp130 signaling and increased IL-7 levels. Furthermore, Kim et $\mathrm{al}^{110}$ also showed that IL- $1 \beta$ and tumor necrosis factor alpha (TNF- $\alpha$ ) increased IL-7 levels by stromal cells in vitro. This result was coupled to the finding that IL-7 markedly induced osteoclastogenic cytokine production by T-cells, which was receptor activator of NF- $\kappa \mathrm{B}$ ligand (RANKL)-dependent while being TNF- $\alpha$ independent. This result strongly suggested a critical link between IL-7/ IL-7R $\alpha$-dependent signaling and STAT protein activation playing a role in the destruction of subchondral bone, which is a characteristic feature of chronically progressive RA. Of note, glucocorticoids that are often employed in the initial therapy of RA inhibited IL-7-mediated signaling (along with IL-4 and -15) in primary human T-cells which was accompanied by inhibition of STAT- 5 activation. ${ }^{112}$

Although STAT-5-mediated signaling via IL-7/IL-7R $\alpha$ was crucial for promoting naïve T-cell survival, the forced expression of constitutively active STAT-5 failed to rescue $\mathrm{CD}^{+}$T-cells in SOCS1 transgenic mice, implying that STAT-5 was necessary but not sufficient for survival of naïve T-cells. ${ }^{106}$ Moreover, employing T-lymphoid cells, Jahn et al ${ }^{113}$ showed that Kit, the transmembrane protein receptor tyrosine kinase for stem cell factor and IL-7R could act synergistically with partial complementation of $\gamma-\mathrm{C}$ or IL-7-mediated signaling occurring via the Kit signaling pathway so that Kit-mediated activation of JAK-3 became IL-7R-dependent. Of note, deficient STAT-5 activation was also found in the Kit mutant YY567/569FF which lacked intrinsic Src activation capacity. This defect could be partially reconstituted in the presence of IL-7R and JAK-3. ${ }^{113}$

\section{IL- 17}

IL-17 exists in six isoforms among which the bioactivity of isoforms IL-17A and $-17 \mathrm{~F}$ is the most thoroughly studied. IL-17 is a T-cell-derived cytokine that is overexpressed in the synovial tissue of RA patients. ${ }^{24,114} \mathrm{IL}-17$ can drive the progression of arthritis in well-validated animal models of RA which was found to be independent of the presence and/or activity of IL- $1 \beta^{57}$ and/or TNF- $\alpha .{ }^{115,116}$ Noteworthy was the finding

Table I IL-6 protein family member-regulated genes

\begin{tabular}{lll}
\hline Cytokine & STAT-regulated genes & Cell target \\
\hline GM-CSF & Survivin & CD34+ hemoprogenitor cells \\
IL-6, sIL-6R & Type II collagen, link protein, & Articular chondrocytes \\
& aggrecan, Sox9 & I00 \\
IL-6 & BCL-3 & Multiple myeloma cell lines \\
Oncostatin M & c-fos, TNF-R, Pcnt, Bcl-3, Pegl0, NIH3T3 STAT3-dependent \\
& Cdo, Cin6, PerqI, Smad9, Boc, CBP, & I02 \\
Oncostatin M & CHI3LI, PLAU, MTA2, EPASI & \\
LIF & DactI, KIf4, KIf5, Rgs I6, Smad7 CcrnI, & UI242MG glioma cell line \\
& Ocln, ler3, Pim I, Cyr6I, Sgk & Mouse embryonic stem cells \\
\hline
\end{tabular}

Abbreviations: GM-CSF, granulocyte macrophage-colony-stimulating factor; IL, interleukin; LIF, leukemia inhibitory factor. 
that a T-cell subset, $\mathrm{T}_{\mathrm{H}} 17$, isolated from RA peripheral blood mononuclear cell preparations had several characteristics that made them distinct from the $\mathrm{T}_{\mathrm{H}} 1 / \mathrm{T}_{\mathrm{H}} 2 \mathrm{~T}$-cell subsets with TNF- $\alpha$, GM-CSF, and IL- 6 among the most prominent pro-inflammatory cytokines produced by $\mathrm{T}_{\mathrm{H}} 17$ cells. ${ }^{25}$ Importantly, IL-23 $3^{21,22,117}$ and over-expression of the retinoic acid receptor-related orphan receptor- $\gamma(\operatorname{ROR}-\gamma)^{118}$ were shown to be potent inducers of IL-17 synthesis and $\mathrm{T}_{\mathrm{H}} 17$ cell differentiation. Moreover, ROR- $\alpha \mathrm{t}$ and ROR- $\gamma \mathrm{t}$ coexpression acting in synergistic fashion was found to further drive the production of $\mathrm{T}_{\mathrm{H}} 17$ differentiation. $\mathrm{T}_{\mathrm{H}} 17$ cells in vitro also secreted IL-21 and -22. ${ }^{119}$ In that regard, Korn et al ${ }^{120}$ showed that the robust production of $\mathrm{T}_{\mathrm{H}} 17$ cells only occurred in the presence of transforming growth factor- $\beta$, IL-6, -21, -23, and ROR- $\alpha \mathrm{t}$ and ROR- $\gamma \mathrm{t}$ which also drove the activation of STAT-3. $\mathrm{T}_{\mathrm{H}} 17$ cells specifically lacking gp130 and STAT-3 failed to differentiate into $T_{\text {reg }}$ cells or express the ROR- $\gamma t$ phenotype indicating that activation of the JAK/STAT-1, -3 signaling pathway was critical for the differentiation of $\mathrm{T}_{\text {reg }}$ cells from $\mathrm{T}_{\mathrm{H}} 17$ cells. ${ }^{121-123}$ Not unexpectedly, two genomewide analyses determined that STAT-dependent targets (eg, IRF8-STAT-3 and NFAT-STAT-3) were regulated at the level of transcription either directly by IL-17, ${ }^{124}$ indirectly by the up regulated expression of IL-6 in response to IL-17, or by 'cross talk' via activation of NF- $\mathrm{KB}$ and PI3K/Akt/mTor pathways. ${ }^{125,126}$ Conversely, IL-17 expression was blocked by IFN- $\gamma$ and IL-4 signaling. ${ }^{127}$

\section{IL- I /IL-23}

IL-23 is a heterodimeric cytokine composed of IL-12p40 and the IL-12p35 cytokine. ${ }^{128,129}$ IL-23 binds to the IL-12 receptor- $\beta_{1}$ (IL-12R $\beta_{1}$ ), which strongly activates JAK2/STAT-1, -3, -4, and -5 but with a weaker STAT-4 activation profile. ${ }^{130}$ Interestingly, different patterns of DNAbinding complexes emerge in response to IL-12 and -23 .

Serum IL-12 and -23 levels are elevated in RA sera and synovial fluid, ${ }^{20,131}$ but neither of these cytokines were decreased in response to conventional therapy of RA with corticosteroids. ${ }^{131}$ At the cellular level, IL-1 $7^{129}$ and IL-1 $\beta^{132}$ stimulated IL-23 synthesis, whereas IL-23 up regulated IL-8 and -6 expression ${ }^{132}$ in cultured RA synovial fibroblasts. The stimulatory effects of IL-17 and IL-1 $\beta$ on IL-23 production were both dependent on activation of the p38 MAPK, PI3K/Akt/mTor, and AP-1 pathways. ${ }^{131,132}$ Conversely, IL-12-induced IFN- $\gamma$ production by human T-cells was also found to be regulated by mTor. ${ }^{133}$

$\mathrm{Xu}$ et $\mathrm{al}^{134}$ showed that DCs that were engineered (ie, 'silenced') to not produce IL-12p35 were capable of blunting T-cell responses. This occurred by dampening the activation of T-cell JAK2, Tyk2, STAT-3, and -4. STAT-4 induced target genes following stimulation of human T-helper cells with IL-12, which included macrophage inflammatory protein- $1 \alpha$ and $-3 \alpha$, IL-1-receptor antagonist, IFN-regulatory factor, v-ets erythroblastosis virus E26 oncogene homolog 1 (Ets)-related transcription factor, CCR5 and the IL-18 receptor. ${ }^{135}$ Of note, Kageyama et $\mathrm{al}^{136}$ showed that a significant decrease in serum IL-23 and macrophage inflammatory protein-3 $\alpha$, but not IL-17, occurred after 3- and 6-month therapy of RA patients with etanercept, an anti-TNF- $\alpha$ fusion protein. Additionally, in a Phase II clinical trial in RA patients, the orally administered IL-12/IL-23 small molecule inhibitor (SMI), STA-5326, down regulated IL-12p35 and IL-12/IL-23p40 at the transcriptional level with decreased $\mathrm{T}_{\mathrm{h}} 1$ responses. ${ }^{130}$

\section{The interferon-mediated pathway}

An extensive analysis of the critical role played by the IFN protein family and the interferon-regulated gene (IFG) pathway in RA, ${ }^{137,138}$ including the emerging role of two newly identified IFN- $\lambda$ protein family members, IL-28A,B and IL-29139 as well as the role of IFN/IFG-dependent pathways in other autoimmune disorders such as SLE ${ }^{140,141}$ and Sjögren's syndrome ${ }^{142}$ is beyond the overall scope of this review. Sufficed, the IFN/IFG-mediated pathway has been extensively studied in these autoimmune diseases and was shown to play an important regulatory role in mediating autoimmune-dependent inflammation.

The following patterns of IFN/IFG-regulated gene responses have emerged in these disease states. Despite the fact that most of the previous studies have focused on the capacity of IFN to activate the JAK/STAT pathway resulting in IRG-mediated responses, ${ }^{33,143,144}$ recent studies have also shown that i) non-STAT-dependent pathways, including, those signaling pathways involving activation of the MAPK components, p38 kinase, and ERK1/2 as well as activation of PI3K/Akt/mTOR signaling were important in transmitting cellular signals that were critical to IRG-mediated metabolism originating from IFN/IFN-receptor-(IFNR)-associated complexes; ${ }^{145-147}$ ii) that Akt activity was crucial for the up regulation of key IFN- $\alpha,-\gamma$ responses ${ }^{148}$ with these IFN- $\alpha,-\gamma-$ mediated responses also reflecting the direct control of IRG activity by $\mathrm{mTOR}^{149}$ at the initiation of translation level; ${ }^{150}$ and iii) that Akt/mTOR substantively regulated the initiation of translation of three IRGs pertinent to autoimmune-mediated inflammation in RA, SLE, and psoriatic arthritis, namely, IFNinduced 17kDa protein (Isg15), Cxc110, and IFN-regulatory factor-7 (Irf7). ${ }^{151-155}$ 
Of note, JAK/STAT rather than Akt/mTOR was shown to regulate IFN- $\alpha$-mediated translation of irf9 and the antiproliferative effect of IFN- $\alpha$ against the ovarian carcinoma cells line, OVCAR3.${ }^{147}$ However, although irf9-RNAi inhibited the activity of TNF-related apoptosis-inducing ligand (TRAIL)induced apoptosis in OVCAR3, STAT-1-RNAi did not, indicating that TRAIL-mediated apoptosis was ifr9-dependent rather than STAT-1-dependent. ${ }^{147}$ In contrast, irf3 was shown to regulate IFN-stimulated response element promoter activity as well as IFN- $\beta$, irf5, irf7, RANTES (regulated upon activation normal T-cell expressed and presumably secreted), IFN-inducible protein-10, MCP-1, and MIP-1 $\alpha$ in response to poly (I-C). Interestingly, irf3 knockdown also blocked the activity of some genes in RA-synovial fibroblasts not generally thought to be mediated by an IRSE such as matrix metalloproteinase (MMP)-3, -9, IL-6, and -8, the latter which required JNK and AP-1 activity. ${ }^{156}$

Finally, Österlund et $\mathrm{al}^{157}$ showed that the binding of an irf to the Type III IFN promoter/IRSE was the critical step regulating the transcription of IRSE-regulated genes. In this regard, IFN- $\lambda-1$ gene responses could be induced by virally-activated irf3 and irf7 thus resembling IFN- $\beta$ gene activation, whereas IFN- $\lambda 2 / 3$ gene expression was mainly controlled by irf7 and thus resembled an IFN- $\alpha$ gene response. The results of this study ${ }^{157}$ also demonstrated that IFN genes could be regulated by both TLR-dependent as well as TLR-independent pathways.

\section{Signaling by the IL- 10 protein family}

The IL-10 protein family of cytokines consists of IL-10, $-19,-20,-22,-24,-26$, and the IFN- $\lambda$ group (IL-28A, $-28 \mathrm{~B}$, and -29) all of which bind to a shared class II of CyRs to form heterodimeric complexes which activate JAK/STAT signaling and thus play a potential role in cell survival and proliferation. ${ }^{158-162}$ During the past decade or so, there has been an increased interest to restore anti-inflammatorymediated events associated with the IL-10-type cytokines that may have become dampened during autoimmune-mediated events. This approach has often taken a somewhat overly simplistic approach. For example, in one study, IL-22 was shown to act synergistically with TNF- $\alpha$, IL- $1 \beta$, and IL-17. ${ }^{159}$ However, under most other conditions, the biological activity of IL-22 did not require cooperation with any of these cytokines so that modifying the biological activity of TNF- $\alpha$, IL-1 $\beta$, and IL-17 would not be expected to abrogate the effects of IL-22 on inflammatory responses.

As discussed previously, autoimmune-mediated disorders such as RA and SLE are characterized by a skewing of $T_{h} 1$ and $T_{h} 2$ T-cell subsets in favor of $T_{h} 1$. Thus, development of $T_{h} 1$ and $T_{h} 2$-cell subsets may simply be related to the biological activity of specific transcription factors; T-bet for $\mathrm{T}_{\mathrm{h}} 1{ }^{163}$ GATA3 for $\mathrm{T}_{\mathrm{h}} 2,{ }^{164,165}$ ROR $\gamma \mathrm{t}$ for Th17 cells, ${ }^{166}$ and the Schnurri (Shn) zinc-finger proteins for memory and resting T-cells. ${ }^{167}$ These transcription factors all appear to play a fundamental role in modulating the ratio of memory $\mathrm{T}_{h} 1$ and $\mathrm{T}_{\mathrm{h}} 2 \mathrm{~T}$-cell subsets. Therefore, regulation of the biological activity of these transcription factors may have significant effects on regulating levels of IL-10 family cytokines. How this phenomenon is actually controlled at the molecular level still remains to be fully elucidated. However, recent evidence indicated that $S h n-2$ was responsible for promoting memory $\mathrm{T}_{\mathrm{h}}$ cell survival, that suppression of additional transcription factors was required for the development of memory $\mathrm{T}_{\mathrm{h}}$ cells and resting $T_{h}$ cells, and for that matter naïve $\mathrm{CD}^{+}$cells could be modulated by repressor proteins such as Shn-2.167 Another factor that may explain reduced IL-10 function and the dysregulation of STAT protein activation in RA and SLE could be related to the recent results reported by Hermann et al ${ }^{168}$ who showed that an IL-10R1 loss of function $\mathrm{G}^{330} \mathrm{~F}$ mutation cloned into HeLa cells resulted in weak induction of both SOCS and STAM after stimulation with IL-10.

Over a decade ago, Riley et al ${ }^{169}$ demonstrated that IL-10 was responsible for suppressing macrophage-derived TNF- $\alpha$. Therefore, macrophages that were STAT-3- or JAK1-deficient could not respond to induction of TNF- $\alpha$ by lipopolysaccharide (LPS). Furthermore, Riley et al ${ }^{169}$ demonstrated that two redundant STAT-3 recruitment sites located at ${ }^{427} \mathrm{YQKQ}^{430}$ and ${ }^{477} \mathrm{YLKQ}^{480}$ were required for all IL-10-dependent effects on B-cells or macrophages. Of note, IL-10-mediated anti-inflammatory effects required the intracellular domain of the IL-10R at the COOH-terminus which contained at least one functional serine phosphorylation site. Thus, it was likely that the progression of autoimmune-mediated arthritis could go on unabated if some or all of these IL-10 functional requirements were lost during the disease process. These results were later confirmed by Ahmed and Ivashkiv ${ }^{170}$ and Herrero et al, ${ }^{171}$ who showed that IL-10-(and IL-6)-mediated signaling could be blunted by activation of pro-inflammatory and stress-activated pathways involving p38 MAPK, JAK-1, and STAT-3. Further, modulation of IFN- $\gamma$ regulated the 'on/off' switch which controlled IL-10-mediated STAT activation and macrophage responses to IL-10.

Several other possibilities that may account for the loss of functional IL-10 in RA were also proposed by Ji et al ${ }^{172}$ and van Roon et al ${ }^{173}$ whereby macrophages become refractory 
to the anti-inflammatory effects of IL-10 when macrophages are continuously exposed to immune complexes in vivo. In addition, macrophage activation by IFN- $\gamma$ required $\mathrm{F}_{\mathrm{c}}$ receptor activation to mediate the suppression of IL-10 signaling, and diminished STAT-1- and IL-10-inducible gene activity with concomitant suppression of pro-inflammatory cytokine production was also dependent on the activity of protein kinase C- $\delta$. More recently, it was shown that IL-27, a member of the IL-12 cytokine family, was capable of priming monocytes to respond to TLR stimulators which were STAT-1 dependent and which altered IL-10 signaling. ${ }^{174}$ Further, IL-27 was found to strongly suppress TLR-induced IL-10 production by human monocytes suggesting that the elevated levels of IL-27 mRNA produced by the macrophages recovered from the synovial fluid of RA patients compared to control macrophages ${ }^{175}$ could be responsible, in part, for abrogating the potential anti-inflammatory effects of IL-10. Importantly, IL-27 mRNA levels did not differ between RA and control macrophages after TLR2 ligation suggesting a mechanism for modulating the effects of IL-27 on IL-10-mediated signaling.

\section{IL-4/IL- I 3}

IL-4 and -13 are produced primarily by $\mathrm{T}_{\mathrm{h}} 2$ cells, mast cells, and basophils. IL-4-mediated signaling is initiated via the binding of IL-4 to two receptors, type I and type II, whereas IL-13-mediated signaling is activated only through binding of IL-13 to the type II receptor. ${ }^{176}$ Both IL-4 and - 13 activate the JAK/STAT pathway, ${ }^{176}$ but evidence has also shown that PI3K/Akt/mTor, ${ }^{43,176}$ Fes tyrosine kinase, insulin receptor substrates, and inositol phosphatases are also activated by IL-4/IL-13. ${ }^{43}$ Additionally, IL-4 was shown to induce phosphorylation of Syk, p38, ERK 1/2, JNK, as well as JAKs-1 and -2, STAT-1 and -6 in neutrophils with IL-4 also increasing the expression of SOCS3 at the mRNA and protein level. ${ }^{177}$

Wang et $\mathrm{al}^{178}$ showed that IL-4/IL-13 activated STAT-1/ STAT-6 in multiple cell types, including smooth muscle, epithelium, endothelium, fibroblasts, and lymphoid cell lines. IL-4 and -13 utilized a common receptor for activation composed of IL-4R $\alpha$ and IL-13R $\alpha 1$, but IL-4 also used IL-4R $\alpha$ and the common $\gamma$ chain for activation of JAK/STAT suggesting a common mechanism among various cell types that regulate IL-4/IL-13-mediated signaling.

The role played by IL-4 and -13 in regulating inflammatory responses in arthritis has also been systematically analyzed. Thus, Morita et al ${ }^{179}$ showed that IL-4 and -13 (as well as IL-10) inhibited the production of IL-1 $\beta$, TNF- $\alpha$,
IL-6, and IL-8 in freshly isolated synovial tissue cells in vitro. IL-4 and -13 also increased the production of IL-1R antagonist protein. However, IFN- $\gamma$ production was suppressed by IL-4 (and IL-10), but not by IL-13. Finally, IL-1 $\beta$-induced RA synovial fibroblast proliferation was inhibited by IL-4 and -13 , but not by IL-10, a result which suggested that if IL-4 and -13 could retain their potency in RA synovial joints, IL-4 and -13 could potentially suppress aberrant synoviocyte proliferation induced by the elevated levels of IL-1 $\beta$.

Proof-of-concept studies to show that IL-4 could ablate arthritic changes were performed by Woods et $\mathrm{al}^{180}$ who showed that adenovirally-directed IL-4 administered to rats with adjuvant-induced arthritis (AIA) showed reduced joint inflammation compared to the empty vector-control group. The reduction in joint inflammation was accompanied by lower levels of IL- $1 \beta$, TNF- $\alpha$, macrophage inhibitory protein-2 (MIP-2), and RANTES chemokine. A reduction in synovial tissue cellularity, vascularization, and bone destruction was also noted. In contrast, Nabbe et $\mathrm{al}^{181}$ showed that local IL-13 gene transfer when prophylactically administered to rodents prior to the development of immune-complexmediated arthritis had a lower frequency of apoptotic chondrocytes and reduced MMP-mediated cartilage proteoglycan degradation, despite the fact that IL-13 gene transfer had little or no effect on inflammatory responses or on MMP-3, $-9,-12$, and -13 mRNA levels.

The results of other studies have also indicated that IL-4 and -13 (but not IL-10) protected human synoviocytes or synovial tissue explants from apoptosis induced by sodium nitroprusside in a dose-dependent manner. ${ }^{182}$ In addition, elevated levels of IL-13 were found in RA sera and synovial fluid compared to normal sera or synovial fluid from OA patients. ${ }^{183}$ Further, IL-13 recovered from RA samples promoted DC maturation and IL-13 production by DC. Of note, DC growth activity could be inhibited by etanercept in vitro which was also associated with diminished IL-13 activity. Lastly, etanercept-treated RA patients who demonstrated noticeable clinical improvement also showed concurrent increases in circulating macrophage-colony stimulating factor (M-CSF), a non-DC, monocyte-specific growth factor. $\mathrm{M}-\mathrm{CSF}$ is known to promote monocyte/macrophage differentiation, to act as a survival factor for osteoclasts ${ }^{184}$ and to activate STAT-5 during myeloid cell differentiation. ${ }^{185}$ However, it remains to be determined if clinical improvement by RA patients in response to etanercept was totally independent of changes in the level of M-CSF.

Three other studies ${ }^{186-188}$ were noteworthy because they have focused on the putative role of IL-4 and -13 in 
suppressing neoangiogenesis in rat AIA. In one study, ${ }^{186}$ intraarticular administration of adenovirus-producing IL-4 reduced synovial tissue vascularization in rat AIA. The reduction in blood vessel density was accompanied by decreased synovial joint inflammation that was also characterized by lower levels of IL-18, CXC chemokine ligand 16 (CXCL16), and LPS-induced CXC chemokine (CXCL5) but with higher levels of endostatin. The antiangiogenic effects induced by adenovirus-producing IL-4 occurred despite persistently high levels of vascular endothelial growth factor in the joints of rats with AIA. In a follow-up study, Haas et al ${ }^{187}$ produced an almost identical result using rats with AIA treated with adenovirus-producing IL-13. The reduction in joint inflammation was characterized by down regulation of IL-18, cytokine-induced neutrophil chemoattractant-1 (CXCL1), CSCL5, and up regulation of endostatin as well as a decrease in the activities of MMP-2 and -9 . Interestingly, neither study examined the extent to which adenovirus-producing IL-4 or -IL-13 altered JAK/STAT or other signaling pathways in rat AIA, although Ruth et al ${ }^{188}$ previously showed that intragraft injection of human CLCL16 which mediated the recruitment of human mononuclear cells to RA synovial tissue implanted in SCID mice was inhibited by antisense oligonucleotides directed toward ERK1/2 MAPK, suggestive of an effect of CLCL16 on the SAP/MAPK pathway.

\section{IL-2-signaling activates STAT proteins}

Mice deficient in IL-2 or its receptor, IL-2R showed an elevated level of lymphocytic proliferation coupled to an autoimmune disorder. ${ }^{189}$ This finding together with the knowledge that IL-2 plays a critical role in regulating T-cell proliferation in vitro ultimately led to the conclusion that constitutive expression of IL- $2 \mathrm{R} \alpha$ on $\mathrm{CD} 4^{+} \mathrm{CD} 25^{+} \mathrm{T}$-cells as well as IL-2/IL-2R $\alpha$ binding was critical for maintaining normal T-cell proliferation and homeostasis. Prior to this discovery, it was already known that IL-2/IL-2R $\alpha$ signaling activated the JAK/STAT pathway with STAT-5a and $-5 \mathrm{~b}$, the principal STAT proteins activated in this process, and that SOCS was the negative regulator of STAT-5a, $-5 \mathrm{~b}$ protein activation by IL-2/IL-2R $\alpha .{ }^{190}$ In this regard, Murawski et al ${ }^{191}$ showed that up regulation and sustained activity of FOXP3 were required for the sustenance of mouse and human $\mathrm{T}_{\text {reg }}$ cells which were also dependent on STAT-5 activation by IL-2. Moreover, Taylor et $\mathrm{al}^{192}$ showed that the STAT-5-driven activation in response to IL-2/IL-2R $\alpha$ was critical for lymphocyte homeostasis and could, in fact, 'supersede' the general requirement for T-cell receptor engagement and cytokine stimulation with other cytokines such as IL-15 as a T-cell proliferation activator. Thus, chronic cellular stressors that limited STAT-5 phosphorylation might be expected to suppress $\mathrm{CD}^{+} \mathrm{CD} 25^{+} \mathrm{FOXP} 3^{+} \mathrm{T}_{\text {reg }}$ cell activity. Such was the case with $\mathrm{CD}^{+}{ }^{+} \mathrm{CD} 25^{+} \mathrm{FOXP} 3^{+} \mathrm{T}_{\text {reg }}$ cells from patients that were chronically infected with hepatitis $\mathrm{C}$ virus. In this particular case, inadequate levels of $\mathrm{CD}^{+} \mathrm{CD} 25^{+} \mathrm{FOXP} 3^{+} \mathrm{T}_{\text {reg }}$ cells were accompanied by up regulation of the interaction between programmed death-ligand-1 (PD-L1) and B7.1 ${ }^{193}$ suggesting that PD-L1 negatively regulated $\mathrm{T}_{\text {reg }}$ cell activity by blocking STAT-5 activation at sites where chronic inflammation was persistently present.

\section{Is epigenetic status a mechanism for regulating STAT-protein expression?}

Recent studies have focused attention on the distinct possibility that epigenetic modifications, including chromatin methylation and histone post-translational alterations, play a critical role in the pathogenesis and progression of RA. ${ }^{194}$ Thus, Karouzakis et al ${ }^{195}$ showed that histone hyperacetylation and elevated microRNA expression were a characteristic of RA synovial fibroblast cultures. Moreover, normal synovial fibroblasts grown in a culture milieu that supported hypermethylation resulted in normal cultured synoviocytes acquiring an RA-like phenotype. One possible interpretation of these results was that aberrant DNA methylation altered the progression of RA by inducing abnormal synoviocyte proliferation and activation. These findings were extended to show that similar epigenetic alterations affecting chromatin and DNA supercoiling occurred in other autoimmune disorders, such as SLE and multiple sclerosis, ${ }^{196}$ whereby epigenetic modifications affected autoreactive lymphocyte development and neural demyelination, respectively. As previously indicated, in RA, DNA methylation and histone modifications were also found to be strong promoters of aberrant synoviocyte proliferation. ${ }^{195,196}$

STAT proteins appear to be particularly sensitive to epigenetic modifications. ${ }^{197}$ For example, Shin et al ${ }^{198}$ showed using normal human T-cells that STAT-4 expressional regulation was associated with the hypermethylated state and STAT-4 gene expression was strongly increased in human T-cells following treatment with a DNA methyltransferase inhibitor. Moreover, methylation exhibited a stronger association with STAT-4 protein expression than that associated with promoter polymorphisms. A similar result was found for the regulation of STAT-6 signaling in human T-cells. ${ }^{199}$ 
Of note, loss of functioning JAKs resulted in an enhancement of heterochromatin gene silencing and the over-expression of heterochromatin protein-1 which correlated with the growth of oncogenic JAK-induced tumors in the absence of any alterations in JAK/STAT-mediated signaling. ${ }^{200}$ These results suggested that epigenetic status was critical for disrupting heterochromatin-mediated tumor suppression characterized by overactivation of JAKs which may have particular relevance for establishing a role for altered JAK activity in autoimmunity.

Finally, Nile et $\mathrm{al}^{201}$ showed using LPS-stimulated macrophages that methylation of a single CpG site in the IL-6 promoter region altered IL-6 gene regulation. Moreover, the IL-6/CpG motif in monocytes from RA patients was undermethylated compared to the IL-6/CpG motif from control monocytes. Although the relevance of these findings to RA requires further study, they may be associated with the elevated levels of IL-6 found in RA synovial fluid and sera as well as the altered responsiveness of IL-6-induced STAT activation ${ }^{2,6,8,14}$ found in human RA synoviocytes and monocytes ex vivo.

\section{Potential drug targets}

The majority of the newer drug treatment strategies for RA and other autoimmune disorders have focused on neutralizing proinflammatory cytokine/CyR interactions, especially those initiated by IL-1, TNF- $\alpha$, and IL- $6 .{ }^{4,5,13,14}$ Other pro-inflammatory cytokines that include IL-17, ${ }^{202,203}$ IL-12/IL-23, ${ }^{204-206}$ IL-7, ${ }^{17,19}$ and IL-7R $\alpha^{207}$ have also been considered as promising targets for drug development for the medical therapy of various forms of inflammatory arthritis, Crohn's disease, and psoriasis. Manipulating DC activity deemed to be critical to the progression of RA has also been contemplated as a viable form of 'cell' therapy. ${ }^{208}$ Drug development strategies for improving the potential disease-modifying effects of anti-inflammatory cytokines such as IL-4/IL-13 and IL-10 must also be formulated but at the present time, the development of experimental strategies to counteract the effects of pro-inflammatory cytokine-induced responses in RA using anti-IL4/Il-13 or anti-IL-10 have lagged behind other experimental approaches. However, in the context of the overall theme of this review, there have been experimental protocols designed to directly target JAK/STAT-mediated signaling. ${ }^{209,210}$ Indeed, several drugs in various current stages of development as specific JAK and/or STAT protein inhibitors are shown in Table 2. In addition to RA, several of these JAK/STAT-specific SMIs are contemplated for use in the treatment of MPDs, renal carcinoma, and malignant glioma.
Table 2 Drug targeting of the JAK/STAT signaling pathway

\begin{tabular}{|c|c|c|c|}
\hline Inhibitor & JAK selectivity & $\begin{array}{l}\text { Potential } \\
\text { indication }\end{array}$ & References \\
\hline CP690550 & JAK3 & RA & 211,212 \\
\hline MS-0I 20 & JAK3 & $\begin{array}{l}\text { Hodgkin's } \\
\text { lymphoma }\end{array}$ & 213 \\
\hline INCB0I 8424 & JAKI/JAK2 & MPD & 214 \\
\hline INCB028050 & & $\mathrm{RA}$ & 215 \\
\hline 420999 & JAKI/2/3 (?) & Osteosarcoma & 216 \\
\hline CYT387 & JAK2 & $\begin{array}{l}\text { Hematologic } \\
\text { malignancy }\end{array}$ & 217 \\
\hline TGI01348 & JAK2 & Polycythemia vera & 218 \\
\hline TGI0I209 & JAK2 & & 219 \\
\hline JS- 124 & JAKI/2/3 (?) & $\begin{array}{l}\text { Glioblastoma } \\
\text { multiforme, } \\
\text { Malignant glioma }\end{array}$ & 220 \\
\hline WPI066 & & Renal carcinoma & 221 \\
\hline CPA-7 & & Malignant glioma & 222 \\
\hline
\end{tabular}

Abbreviations: JAK, Janus kinase; MPD, myeloproliferative disease; RA, rheumatoid arthritis; STAT, signal transducers and activators of transcription.

\section{Conclusions}

Activation of the JAK/STAT signaling pathway initiated by the interaction of pro-inflammatory and/or anti-inflammatory cytokines with their respective CyRs regulate a host of immune-mediated inflammatory responses that are highly relevant to the pathogenesis and progression of RA and other autoimmune disorders. Although the importance of STAT protein activation in RA is undeniable and has resulted in the development and testing of several JAK-specific SMIs in well-validated animal models of inflammatory arthritis and now in RA clinical trials, there are other potential targets for RA intervention that should not be overlooked. Thus, circulating hormonal axes relevant to chondrogenesis and cartilage repair involving insulin-like growth factor binding protein and the growth hormone/IGF-1 nuclear receptor peroxisome proliferator-activated receptor pathway, the latter participating in the maintenance of normal cartilage homeostasis, can also initiate STAT protein activation. ${ }^{223,224}$ The extent to which non-cytokine mediators should be further studied to determine whether or not they promote or inhibit JAK-specific activation or if they affect cartilage repair in RA via JAK/STAT or any of the other parallel signaling pathways seems appropriate and worthwhile.

There had been strong implications based on the results from well-validated animal models of inflammatory arthritis that suppression of the SAP/MAPK pathway and p38 kinase, in particular, dampens the severity of bone loss in experimental arthritis. ${ }^{225}$ However, there has been little clinical efficacy obtained when p38 kinase isoform-specific SMIs were employed in human RA clinical trials. ${ }^{226,227}$ In the meantime, 
significant progress has already been made in determining the efficacy, safety, and tolerability of the orally administered JAK3-specific SMI, CP690550 in RA clinical trials. The use of CP690550 for future RA therapy will hinge on data forthcoming from the currently ongoing phase III clinical trial.

\section{Acknowledgment}

The experimental data produced by the Arthritis Research Laboratory at CWRU and discussed in this paper were supported, in part, by an Investigator-Initiated Project Award (MAF-021) to CJM from Takeda Pharmaceuticals of North America.

\section{Disclosure}

The author reports no conflict of interest in this work.

\section{References}

1. Ivashkiv LB, Hu X. Signaling by STATs. Arthritis Res Ther. 2004;6(4): 159-168.

2. Walker JG, Smith MD. The Jak-STAT pathway in rheumatoid arthritis. J Rheumatol. 2005;32(9):1650-1653.

3. Murray PJ. The JAK-STAT signaling pathway: input and output integration. J Immunol. 2007;178(5):2623-2629.

4. Malemud CJ, Reddy SK. Targeting cytokines, chemokines and adhesion molecules in rheumatoid arthritis. Curr Rheumatol Rev. 2008;4(4):219-234.

5. Malemud CJ, Miller AH. Pro-inflammatory cytokine-induced SAPK/ MAPK and JAK/STAT in rheumatoid arthritis and the new antidepression drugs. Expert Opin Ther Targets. 2008;12(2):171-183.

6. Walker JG, Ahern MJ, Coleman M, et al. Expression of Jak3, STAT1, STAT4, and STAT6 in inflammatory arthritis: unique Jak3 and STAT4 expression in dendritic cells in seropositive rheumatoid arthritis. Ann Rheum Dis. 2006;65(2):149-156.

7. Barton A, Thomson W, Ke X, et al. Re-evaluation of putative rheumatoid arthritis susceptibility genes in the post-genome wide association study era and hypothesis of a key pathway underlying susceptibility. Hum Mol Genet. 2008;17(15):2274-2279.

8. Remmers EF, Plenge RM, Lee AT, et al. STAT4 and the risk of rheumatoid arthritis and systemic lupus erythematosus. $N$ Engl J Med. 2007;357(10):977-986.

9. Imboden JB. The immunopathogenesis of rheumatoid arthritis. Annu Rev Pathol. 2009;4:417-434.

10. Ivashkiv LB. Type I interferon modulation of cellular responses to cytokines and infectious pathogens: potential role in SLE pathogenesis. Autoimmunity. 2003;36(8):473-479.

11. Glas J, Seiderer J, Nagy M, et al. Evidence for STAT4 as a common autoimmune gene: rs7574865 is associated with colonic Crohn's disease and early disease onset. PLoS One. 2010;5(4):e10373.

12. Hebenstreit D, Horejs-Hoeck J, Duschl A. JAK/STAT-dependent gene regulation by cytokines. Drug News Perspect. 2005;18(4): 243-249.

13. Ishihara K, Hirano T. IL-6 in autoimmune disease and chronic inflammatory proliferative disease. Cytokine Growth Factor Rev. 2002; 13(4-5):357-368.

14. Malemud CJ. Recent advances in neutralizing the IL-6 pathway in arthritis. Open Access Rheumatol Res Rev. 2009;1:133-150.

15. Saini M, Pearson C, Seddon B. Regulation of T cell-dendritic cell interactions by IL-7 governs T-cell activation and homeostasis. Blood. 2009;113(23):5793-5800.

16. Vogt TK, Link A, Perrin J, Finke D, Luther SA. Novel function for interleukin-7 in dendritic cell development. Blood. 2009;113(17): 3961-3968.
17. Churchman SM, Ponchel F. Interleukin-7 in rheumatoid arthritis. Rheumatology (Oxford). 2008;47(6):753-759.

18. Schmutz S, Bosco N, Chappaz S, et al. Cutting edge: IL-7 regulates the peripheral pool of adult ROR $\gamma^{+}$lymphoid tissue inducer cells. J Immunol. 2009;183(4):2217-2221.

19. Malemud CJ. The discovery of novel experimental therapies for inflammatory arthritis. Mediators Inflam. 2009;2009:698769.

20. Cordero OJ, Salgado FJ, Mera-Varela A, Nogueira M. Serum interleukin-12, interleukin-15, soluble CD26, and adenosine deaminase in patients with rheumatoid arthritis. Rheumatol Int. 2001;21(2): 69-74.

21. Aggarwal S, Ghilardi N, Xie M-H, de Sauvage FJ, Gurney AL. Interleukin-23 promotes a distinct $\mathrm{CD} 4 \mathrm{~T}$ cell activation state characterized by the production of interleukin-17. J Biol Chem. 2003;278(3): 1910-1914.

22. Sheibanie AF, Khayrullina T, Safadi FF, Ganea D. Prostaglandin $\mathrm{E}_{2}$ exacerbates collagen-induced arthritis in mice through the inflammatory interleukin-23/interleukin-17 axis. Arthritis Rheum. 2007;56(8):2608-2619.

23. Paradowska-Gorycka A, Grzybowska-Kowalczyk A, Wojtecka-Lukasik E, Maslinski S. IL-23 in the pathogenesis of rheumatoid arthritis. Scand J Immunol. 2010;71(3):134-145.

24. Lubberts E. The role of IL-17 and family members in the pathogenesis of arthritis. Curr Opin Investig Drugs. 2003;4(5):572-577.

25. Furuzawa-Carballeda J, Vargas-Rojas MI, Cabral AR. Autoimmune inflammation from the Th17 perspective. Autoimmun Rev. 2007;6: 169-175.

26. Sarkar S, Tesmer LA, Hindnavis V, Endres JL, Fox DA. Interleukin-17 as a molecular target in immune-mediated arthritis: immunoregulatory properties of genetically modified murine dendritic cells that secrete interleukin-4. Arthritis Rheum. 2007;56(1):89-100.

27. Toh ML, Kawashima M, Hot A, Miossec P, Miossec P. Role of IL-17 in the Th1 systemic defects in rheumatoid arthritis through selective IL-12Rß2 inhibition. Ann Rheum Dis. 2010;69(8):1562-1567.

28. Horvath CM. The Jak-STAT pathway stimulated by interferon alpha or interferon beta. Sci STKE. 2004;2004(260):tr10.

29. Schindler C, Plumlee C. Interferons pen the JAK-STAT pathway. Semin Cell Dev Biol. 2008;19(4):311-318.

30. Gough DJ, Levy DE, Johnstone RW, Clarke CJ. IFN $\gamma$ signaling - does it mean JAK-STAT? Cytokine Growth Factor Rev. 2008;19(5-6): 383-394.

31. Hu X, Ivashkiv LB. Cross-regulation of signaling pathways by interferon- $\gamma$ : implications for immune responses and autoimmune diseases. Immunity. 2009;31(4):539-550.

32. Molinero LL, Yang J, Gajewski T, Abraham C, Farrar MA, Alegre ML. CARMA1 controls an early checkpoint in the thymic development of FoxP3 ${ }^{+}$regulatory T cells. J Immunol. 2009;182(11):6736-6743.

33. Malemud CJ, Pearlman E. Targeting JAK/STAT signaling pathway in inflammatory diseases. Curr Signal Transduct Ther. 2009; 4:201-221.

34. Jongbloed SL, Benson RA, Nickdel MB, Garside P, McInnes IB, Brewer JM. Plasmacytoid dendritic cells regulate breach of selftolerance in autoimmune arthritis. $J$ Immunol. 2009;182(2):963-968.

35. Sozzani S, Vermi W, Prete AD, Fracchetti F. Trafficking properties of plasmacytoid dendritic cells in health and disease. Trends Immunol. 2010;31(7):270-277.

36. Conigliaro P, Perricone C, Benson RA, et al. The type I IFN system in rheumatoid arthritis. Autoimmunity. 2010;43(3):220-225.

37. Liu H, Leung BP. $\mathrm{CD} 4{ }^{+} \mathrm{CD} 25^{+}$regulatory $\mathrm{T}$ cells in health and disease. Clin Exp Pharmacol Physiol. 2006;33(5-6):519-524.

38. Han GM, O'Neill-Andersen NJ, Zurier RB, Lawrence DA. $\mathrm{CD} 4{ }^{+} \mathrm{CD} 25$ high $\mathrm{T}$ cell numbers are enriched in the peripheral blood of patients with rheumatoid arthritis. Cell Immunol. 2008;253(1-2): 92-101.

39. Boissier MC, Assier E, Biton J, Denys A, Falgarone G, Bessis N. Regulatory $\mathrm{T}$ cells (Treg) in rheumatoid arthritis. Joint Bone Spine. 2009;76(1):10-14. 
40. Crome SQ, Wang AY, Levings MK. Translational mini-review series on Th17 cells: function and regulation of human T helper 17 cells in health and disease. Clin Exp Immunol. 2010;159(2):109-119.

41. van der Vliet HJ, Nieuwenhuis EE. IPEX as a result of mutations in FOXP3. Clin Dev Immunol. 2007;2007:89017.

42. Bacchetta R, Passerini L, Gambineri E, et al. Defective regulatory and effector T cell functions in patients with FOXP3 mutations. J Clin Invest. 2006;116(6):1713-1722.

43. Jiang H, Harris MB, Rothman P. IL-4/IL-13 signaling beyond JAK/ STAT. J Allergy Clin Immunol. 2000;105(6 Pt 1):1063-1070.

44. Donnelly RP, Dickensheets H, Finbloom DS. The interleukin-10 signal transduction pathway and regulation of gene expression in mononuclear phagocytes. J Interferon Cytokine Res. 1999;19(6):563-573.

45. Heim MH. The Jak-STAT pathway: cytokine signalling from the receptor to the nucleus. J Recept Signal Transduct Res. 1999;19(1-4):75-120.

46. Spadaro A, Rinaldi T, Riccieri V, Taccari E, Valesini G. Interleukin-13 in autoimmune rheumatic diseases: relationship with autoantibody profile. Clin Exp Rheumatol. 2002;20(2):213-216.

47. Spadaro A, Rinaldi T, Riccieri V, Valesini G, Taccari E. Interleukin 13 in synovial fluid and serum of patients with psoriatic arthritis. Ann Rheum Dis. 2002;61(2):174-176.

48. Lejuene D, Dumoutier L, Constantinescu S, Kruijer W, Schuringa JJ, Renauld JC. Interleukin-22 (IL-22) activates the JAK/STAT, ERK, JNK and p38 MAP kinase pathways in a rat hepatoma cell line. Pathways that are shared with and distinct from IL-10. J Biol Chem. 2002;277(37):33676-33682.

49. Travagli J, Letourneur M, Bertoglio J, Pierre J. STAT6 and Ets-1 form a stable complex that modulates Socs-1 expression by interleukin-4 in ketatinocytes. J Biol Chem. 2004;279(34):35183-35192.

50. Davey GM, Heath WR, Starr R. SOCS1: a potent and multifaceted regulator of cytokines and cell-mediated inflammation. Tissue Antigens. 2006;67(1):1-9.

51. O’Shea JJ, Murray PJ. Cytokine signaling modules in inflammatory responses. Immunity. 2008;28(4):477-487.

52. Tsuji-Takayama K, Suzuki M, Yamamoto M, et al. IL-2 activation of STAT5 enhances production of IL-10 from human cytotoxic regulatory T cells, HOZOT. Exp Hematol. 2008;36(2):181-192.

53. Heinrich PC, Behrmann I, Haan S, Hermanns HM, Müller-Newen G, Schaper F. Principles of interleukin (IL)-6-type cytokine signalling and its regulation. Biochem J. 2003;374(Pt 1):1-20.

54. Decker T, Kovarik P. Serine phosphorylation of STATs. Oncogene. 2000;19(21):2628-2637.

55. Maritano D, Sugrue ML, Tininini S, et al. The STAT3 isoforms $\alpha$ and $\beta$ have unique and special functions. Nat Immunol. 2004;5(4):401-409.

56. El Kasmi KC, Holst J, Coffre M, et al. General nature of the STAT3activated anti-inflammatory response. J Immunol. 2006;177(11): 7880-7888.

57. Malemud CJ, Gillespie HJ. The role of apoptosis in arthritis. Curr Rheumatol Rev. 2005;1(2):131-142.

58. Tamai M, Kawakami A, Tanaka F, et al. Significant inhibition of TRAIL-mediated fibroblast-like synovial cell apoptosis by IFN- $\gamma$ through JAK/STAT pathway by translational regulation. J Lab Clin Med. 2006;147(4):182-190.

59. Chetoui N, Boisvert M, Gendron S, Aoudjit F. Interleukin-7 promotes the survival of human $\mathrm{CD}^{+}$effector/memory $\mathrm{T}$ cells by upregulating Bcl-2 proteins and activating the JAK/STAT signalling pathway. Immunology. 2010;130(3):418-426.

60. Blank VC, Peńa C, Roguin LP. STAT1, STAT3 and p38MAPK are involved in the apoptotic effect induced by a chimeric cyclic interferon$\alpha 2 b$ peptide. Exp Cell Res. 2010;316(4):603-614.

61. Yoshimura A, Nishinakamura H, Matsumura Y, Hanada T. Negative regulation of cytokine signaling and immune responses by SOCS proteins. Arthritis Res Ther. 2005;7(3):100-110.

62. Malemud CJ. Dysfunctional immune-mediated inflammation in rheumatoid arthritis dictates that development of anti-rheumatic disease drugs target multiple intracellular signaling pathways. Anti Inflamm Anti Allergy Agents Med Chem. In press 2010.
63. Hutcheson J, Perlman H. Apoptotic regulators and RA. Curr Rheumatol Rev. 2008;4(4):254-258.

64. van de Loo FA, Veenbergen S, van den Berg WB. Targeting growth factors in arthritis: a rational for restoring the IGF-1 response in chondrocytes. Curr Rheumatol Rev. 2008;4(4):266-276.

65. Tallheden T, Dennis JE, Lennon DP, Sjögren-Jansson E, Caplan AI, Lindahl A. Phenotypic plasticity of human articular chondrocytes. J Bone Joint Surg Am. 2003;85-A Suppl 2:93-100.

66. Neumann A, Dennis JE, Aigner J, et al. Tissue engineering of autologous cartilage grafts in three-dimensional in vitro macroaggregate culture system. Tissue Eng. 2004;10(11-12):1695-1706.

67. Samanta AK, Lin H, Sun T, Kantarjian H, Arlinghaus RB. Janus kinase 2: a critical target in chronic myelogenous leukemia. Cancer Res. 2006;66(13):6468-6472.

68. Huang C, Yang C, Jiang T, Huang K, Cao J, Qiu Z. Effects of IL-6 and AG490 on regulation of Stat 3 signaling pathway and invasion of pancreatic cancer cells in vitro. J Exp Clin Cancer Res. 2010;29(1):51.

69. de Vos J, Jourdan M, Tarte K, Jasmin C, Klein B. JAK2 tyrosine kinase inhibitor tyrphostin AG490 downregulates the mitogen-activated protein kinase (MAPK) and signal transducer and activator of transcription (STAT) pathways and induces apoptosis in myeloma cells. $\mathrm{Br} J$ Haematol. 2000;109(4):823-828.

70. Seo IA, Lee HK, Shin YK, et al. Janus kinase 2 inhibitor AG490 inhibits the STAT3 signaling pathway by suppressing protein translation of gp130. Korean J Physiol Pharmacol. 2009;13(4):131-138.

71. Wisler BA, Dennis JE, Malemud CJ. New organ-specific pharmacological strategies interfering with signaling pathways in inflammatory disorders/autoimmune disorders. Curr Signal Transduct Ther. In press 2010 .

72. Legendre F, Bogdanowicz P, Boumediene K, Pujol J-P. Role of interleukin 6 (IL-6)/IL-6R-induced signal transducers and activators of transcription and mitogen-activated protein kinase/extracellular. J Rheumatol. 2005;32(7):1307-1316.

73. Hu X, Chen J, Wang L, Ivashkiv LB. Crosstalk between Jak-STAT, Toll-like receptor, and ITAM-dependent pathways in macrophage activation. J Leukoc Biol. 2007;82(2):237-243.

74. Abram CL, Lowell CA. The expanding role for ITAM-based signaling pathways in immune cells. Sci STKE. 2007;2007(377): re2.

75. Chen AT, Prchal JT. JAK2 kinase inhibitors and myeloproliferative disorders. Curr Opin Hematol. 2010;17(2):110-116.

76. McQueen FM, Dalbeth N. Will Jill come tumbling after? The case for a JAK2-type mutation as a prequel to the connective tissue disorders. Med Hypotheses. 2009;73(5):651-654.

77. Smolen JS, Maini RN. Interleukin-6: a new therapeutic target. Arthritis Res Ther. 2006;8 Suppl 2:S5.

78. Crawford M, Moreland L. Interleukin-6 receptor antagonist as therapy for rheumatoid arthritis. Curr Rheumatol Rep. 2007;9(5):393-394.

79. Darnell JE Jr, Kerr IM, Stark GR. Jak-STAT pathways and transcriptional activation in response to IFNs and other extracellular signaling proteins. Science. 1994;264(5164):1415-1421.

80. Strobl B, Arulampalam V, Is'harc H, et al. A completely foreign receptor can mediate an interferon- $\gamma$ response. EMBO J. 2001;20(19): 5431-5442.

81. Leonard WJ, O'Shea JJ. Jaks and STATs: biological implications. Annu Rev Immunol. 1998;16:293-322.

82. Sehgal PB. Paradigm shifts in the cell biology of STAT signaling. Semin Cell Dev Biol. 2008;19(4):329-340.

83. Yang J, Liao X, Agarwal MK, Barnes L, Auron PE, Stark GR. Unphosphorylated $\mathrm{STAT}_{3}$ accumulates in response to IL-6 and activates transcription of binding to NFкB. Genes Dev. 2007;21(11): 1396-1408.

84. Cheon H, Stark GR. Unphosphorylated STAT1 prolongs the expression of interferon-induced immune regulatory genes. Proc Natl Acad Sci US A. 2009;106(23):9373-9378.

85. Malemud CJ. Suppression of autoimmune arthritis by small molecule inhibitors of the JAK/STAT pathway. Pharmaceuticals. 2010;3(5): 1446-1455. 
86. Zhang L, Badgwell DB, Bevers JJ 3rd, et al. IL-6 signaling via the STAT3/SOCS3 pathway: functional analysis of the conserved $\mathrm{STAT}_{3}$ N-domain. Mol Cell Biochem. 2006;288(1-2):179-189.

87. Banninger G, Reich NC. STAT2 nuclear trafficking. J Biol Chem. 2004;279(38):39199-39206.

88. Darnell JE Jr. STATS and gene regulation. Science. 1997;277(5332): $1630-1635$.

89. Jaruga B, Hong F, Kim W-H, Gao B. IFN- $\gamma /$ STAT1 acts as a proinflammatory signal in $\mathrm{T}$ cell-mediated hepatitis via induction of multiple chemokines and adhesion molecules: a critical role of IRF-1. Am J Physiol Gastrointest Liver Physiol. 2004;287(5):G1044-G1052.

90. Chen Z, Lund R, Aittokallio T, Kosonen M, Nevalainen O, Lahesmaa R. Identification of novel IL-4/Stat6-regulated genes in T lymphocytes. J Immunol. 2003;171(7):3627-3635.

91. Gimeno R, Lee CK, Schindler C, Levy DE. Stat1 and Stat2 but not Stat 3 arbitrate contradictory growth signals elicited by alpha/beta interferon in T lymphocytes. Mol Cell Biol. 2005;25(13):5456-5465.

92. Guo L, Wei G, Zhu J, et al. IL-1 family members and STAT activators induce cytokine production by Th2, Th17 and Th1 cells. Proc Natl Acad Sci U S A. 2009;106(32):13463-13468.

93. Zhu J, Guo L, Watson CJ, Hu-Li J, Paul WE. Stat6 is necessary and sufficient for IL-4's role in Th2 differentiation and cell expansion. J Immunol. 2001;166(12):7276-7281.

94. Kaplan MH. STAT4. A critical regulator of inflammation in vivo. Immunol Res. 2005;31(3):231-242.

95. Akira S. IL-6-regulated transcription factors. Int J Biochem Cell Biol. 1997;29(12):1401-1418.

96. Heinrich PC, Behrmann I, Müller-Newen G, Schaper F, Graeve L. Interleukin-6-type cytokine signalling through the gp130/Jak/STAT pathway. Biochem J. 1998;334(Pt 2):297-314.

97. Hintzen C, Haan C, Tuckermann JP, Heinrich PC, Hermanns HM. Oncostatin-M-induced and constitutive activation of the JAK2/ STAT5/CIS pathway suppresses CCL1, but not CCL7 and CCL8, chemokine expression. J Immunol. 2008;181(10):7341-7349.

98. Cvijic H, Bauer K, Löffler D, et al. Co-activator SRC-1 is dispensable for transcriptional control by STAT3. Biochem J. 2009;420(1): $123-132$.

99. Andreas K, Häupl T, Lübke C, et al. Antirheumatic drug response signatures in human chondrocytes: potential molecular targets to stimulate cartilage regeneration. Arthritis Res Ther. 2009;11(1):R15.

100. Gu L, Chiang KY, Zhu N, Findley HW, Zhou M. Contribution of STAT3 to the activation of survivin by GM-CSF in CD34+ cell lines. Exp Hematol. 2007;35(6):957-966.

101. Legendre F, Dudhia J, Pujol J-P, Bogdanowicz P. JAK/STAT but not ERK1/ERK2 pathway mediates interleukin (IL)-6/soluble IL-6R downregulation of Type II collagen, aggrecan core, and link protein transcription in articular chondrocytes. Association with a down-regulation of SOX9 expression. J Biol Chem. 2003;278(5):2903-2912.

102. Brocke-Heidrich $\mathrm{K}$, Ge B, Cvijic H, et al. BCL3 is induced by IL-6 via Stat3 binding to intronic enhancer HS4 and represses its own transcription. Oncogene. 2006;25(55):7297-7304.

103. Snyder M, Huang XY, Zhang JJ. Identification of novel Stat3 target genes for control of growth and differentiation. $J$ Biol Chem. 2008;283(7):3791-3798.

104. Krona A, Aman P, Orndal C, Josefsson A. Oncostatin M-induced genes in human astrocytoma. Int J Oncol. 2007;31(6):1457-1463.

105. Bourillot PY, Aksoy I, Schreiber V, et al. Novel STAT3 target genes exert distinct roles in the inhibition of mesoderm and endoderm differentiation in cooperation with Nanog. Stem Cells. 2009;27(8): 1760-1771.

106. Seki Y, Yang J, Okamoto M, et al. IL-7/STAT5 cytokine signaling pathway is essential but insufficient for maintenance of naïve CD4 T cell survival in peripheral lymphoid organs. J Immunol. 2007;178(1): 262-270.

107. Benczik M, Gaffen SL. The interleukin (IL)-2 family cytokines: survival and proliferation signaling pathways in T lymphocytes. Immunol Invest. 2004;33(2):109-142.
108. Khaled AR, Li WQ, Huang J. Bax deficiency partially corrects interleukin-7 receptor $\alpha$ deficiency. Immunity. 2002;17(5):561-573.

109. Khaled AR, Durum SK. Death and Baxes: mechanisms of lymphotrophic cytokines. Immunol Rev. 2003;193:48-57.

110. Kim H-R, Hwang K-A, Park S-H, Kang I. IL-7 and IL-15: biology and roles in $\mathrm{T}$ cell immunity in health and disease. Crit Rev Immunol. 2008;28(4):325-339.

111. Sawa S-I, Kamimura D, Jin G-H, et al. Autoimmune arthritis associated with mutated interleukin (IL-6) receptor gp130 is driven by STAT3/ IL-7-dependent homeostatic proliferation of $\mathrm{CD}^{+}{ }^{+} \mathrm{T}$ cells. $J$ Exp Med. 2006;203(6):1459-1470.

112. Bianchi M, Meng C, Ivashkiv LB. Inhibition of IL-2-induced JakSTAT signaling by glucocorticoids. Proc Natl Acad Sci U S A. 2000;97(17):9573-9578.

113. Jahn T, Sindhu S, Gooch S, et al. Direct interaction between Kit and the interleukin-7 receptor. Blood. 2007;110(6):1840-1847.

114. Chabaud M, Durand JM, Buchs N, et al. Human interleukin-17: a T cell-derived proinflammatory cytokine produced by the rheumatoid synovium. Arthritis Rheum. 1999;42(5):963-970.

115. Lubberts E, Koenders MI, van den Berg WB. The role of T-cell interleukin-17 in conducting destructive arthritis: lessons from animal models. Arthritis Res Ther. 2005;7(1):29-37.

116. Koenders MI, Lubberts E, van de Loo FAJ, et al. Interleukin-17 acts independently of TNF-alpha under arthritic conditions. J Immunol. 2006;176(10):6262-6269.

117. Boniface K, Blom B, Liu YJ, de Waal Malefyt R. From interleukin-23 to T-helper 17 cells: human T-helper cell differentiation revisited. Immunol Rev. 2008;226:132-146.

118. Yang XO, Pappu BP, Nurieva R, et al. T helper 17 lineage differentiation is programmed by orphan nuclear receptors ROR $\alpha$ and ROR $\gamma$. Immunity. 2008;28(1):29-39.

119. Takatori H, Kanno Y, Chen Z, O'Shea JJ. New complexities in helper $\mathrm{T}$ cell fate determination and the implications for autoimmune diseases. Mod Rheumatol. 2008;18(6):533-541.

120. Korn T, Bettelli E, Oukka M, Kuchroo VK. IL-17 and Th17 cells. Annu Rev Immunol. 2009;27:485-517.

121. Nishihara M, Ogura H, Ueda N, et al. IL-6-gp130-STAT3 in T cells directs the development of IL-17+ $\mathrm{Th}$ with a minimum effect on that of $\mathrm{T}_{\text {reg }}$ in the steady state. Int Immunol. 2007;19(6):695-702.

122. de Beaucoudrey L, Puel A, Filipe-Santos O, et al. Mutations in STAT3 and IL12RB1 impair the development of human IL-17-producing T cells. J Exp Med. 2008;205(7):1543-1550.

123. Chaudhry A, Rudra D, Treuting P, et al. CD4 $4^{+}$regulatory $\mathrm{T}$ cells control TH17 responses in a Stat3-dependent manner. Science. 2009; 326(5955):986-991.

124. Lee Y-H, Benary M, Baumgrass R, Herzel H. Prediction of regulatory transcription factors in $\mathrm{T}$ helper cell differentiation and maintenance. Genome Inform. 2010;22:84-94.

125. Hwang SY, Kim JY, Kim KW, et al. IL-17 induces production of IL-6 and IL-8 in rheumatoid arthritis synovial fibroblasts via NF-KB and PI3-kinase/Akt-dependent pathways. Arthritis Res Ther. 2004;6(2):R120-R128.

126. Zrioual S, Ecochard R, Tournadre A, Lenief V, Cazalis M-A, Miossec P. Genome-wide comparison between IL-17A- and IL-17F-induced effects in human rheumatoid arthritis synoviocytes. J Immunol. 2009; 182(5):3112-3120.

127. Lexberg MH, Taubner A, Förster A, et al. Th memory for interleukin-17 expression is stable in vivo. Eur J Immunol. 2008;38(10):2654-2664.

128. Gee K, Guzzo C, Che Mat NF, Ma W, Kumar A. The IL-12 family of cytokines in infection, inflammation and autoimmune disorders. Inflamm Allergy Drug Targets. 2009;8(1):40-52.

129. Partham C, Chirica M, Timans J, et al. A receptor for the heterodimeric cytokine IL-23 is composed of IL-12R ${ }^{\beta} 1$ and a novel cytokine receptor subunit, IL-23R. J Immunol. 2002;168(11):5699-5708.

130. Wada Y, Lu R, Zhou D, et al. Selective abrogation of the Th1 response by STA-5326, a potent IL-12/IL-23 inhibitor. Blood. 2007;109(3): 1156-1164. 
131. Kim H-R, Cho M-L, Kim K-W, et al. Up-regulation of IL-23p19 expression in rheumatoid arthritis synovial fibroblasts by IL-17 through PI3-kinase, NFKB and p38 MAPK-dependent signalling pathways. Rheumatology (Oxford). 2007;46(1):57-64.

132. Liu FL, Chen $\mathrm{CH}$, Chu SJ, et al. Interleukin (IL)-23p19 expression induced by IL-1 $\beta$ in human fibroblast-synoviocytes with rheumatoid arthritis via active nuclear factor $\mathrm{KB}$ and $\mathrm{AP}-1$ dependent pathway. Rheumatology (Oxford). 2007;46(8):1266-1273.

133. Kusaba H, Ghosh P, Derin R, et al. Interleukin-12-induced interferon- $\gamma$ production by human peripheral blood $\mathrm{T}$ cells is regulated by mammalian target of rapamycin (mTOR). $J$ Biol Chem. 2005;280(2):1037-1043

134. Xu H, Zhang Y, Hua Y, Chen T, Wang H, Wu W. IL-12 p35 silenced dendritic cells modulate immune responses by blocking IL-12 signaling through JAK-STAT pathways in T lymphocytes. Biochem Biophys Res Commun. 2007;353(3):812-816.

135. Lund R, Chen Z, Scheinin J, Lahesmaa R. Early target genes of IL-12 and STAT4 signaling in Th cells. $J$ Immunol. 2004;172(11): 6775-6782.

136. Kageyama Y, Ichikawa T, Nagafusa T, Torikai E, Shimazu M, Nagano A. Etanercept reduces the serum levels of interleukin-23 and macrophage inflammatory protein- $3 \alpha$ in patients with rheumatoid arthritis. Rheumatol Int. 2007;28(2):137-143.

137. Sozzani S, Bosisio D, Scarsi M, Tincani A. Type I interferons in systemic autoimmunity. Autoimmunity. 2010;43(3):196-203.

138. Biswas PS, Bhagat G, Pernis AB. IRF4 and its regulators: insights into the pathogenesis of inflammatory arthritis. Immunol Rev. 2010; 233(1):79-96.

139. Uzé G, Monneron D. IL-28 and IL-29: newcomers to the interferon family. Biochimie. 2007;89(6-7):729-734.

140. Dong J, Wang QX, Zhou CY, Ma XF, Zhang YC. Activation of STAT1 signalling pathway in lupus nephritis in MRL/lpr mice. Lupus. 2007;16(2):101-109.

141. Rönnblom L, Elkon KB. Cytokines as therapeutic targets in SLE. Nat Rev Rheumatol. 2010;6(6):339-347.

142. Roescher N, Tak PP, Illei GG. Cytokines in Sjögren's syndrome: potential therapeutic targets. Ann Rheum Dis. 2010;69(6): 945-948.

143. Christova R, Jones T, Wu PJ, et al. P-STAT1 mediates higher-order chromatin remodeling of the human MHC in response to IFN $\gamma . J$ Cell Sci. 2007;120(Pt 18):3262-3270.

144. Vogl C, Flatt T, Fuhrmann B, et al. Transcriptome analysis reveals a major impact of JAK protein tyrosine kinase 2 (Tyk2) on the expression of interferon-responsive and metabolic genes. BMC Genomics. 2010;11:199.

145. Watling D, Carmo CR, Kerr IM, Costo-Pereira AP. Multiple kinases in the interferon- $\gamma$ response. Proc Natl Acad Sci U SA. 2008;105(16): 6051-6056.

146. Joshi S, Kaur S, Kroczynska B, Platanias LC. Mechanisms of mRNA translation of the interferon stimulated genes. Cytokine. 2010;52 (1-2):123-127.

147. Tsuno T, Mejido J, Zhao T, Schmeisser H, Morrow A, Zoon KC. IRF9 is a key factor for eliciting the anti-proliferative activity of IFN- $\alpha$. J Immunother. 2009;32(8):803-816.

148. Kaur S, Uddin S, Platanias LC. The PI3' kinase pathway in interferon signaling. J Interferon Cytokine Res. 2005;25(12):780-787.

149. Kaur S, Sassano A, Dolniak B, et al. Role of the Akt pathway in mRNA translation of interferon-stimulated genes. Proc Natl Acad Sci U S A. 2008;105(12):4808-4813.

150. Kaur S, Katsoulidis E, Platanias LC. Akt and mRNA translation by interferons. Cell Cycle. 2008;7(14):2112-2116.

151. Kaur S, Sassano A, Joseph AM, et al. Dual regulatory roles of phosphatidylinositol-3-kinase in IFN-signaling. J Immunol. 2008; 181(10):7316-7323.

152. Andreas K, Lübke C, Häupl T, et al. Key regulatory molecules of cartilage destruction in rheumatoid arthritis: an in vitro study. Arthritis Res Ther. 2008;10(1):R9.
153. Waldburger J-M, Firestein GS. Signaling pathways in rheumatoid arthritis. In: Tak P-P, editor. Progress in Inflammation Research. Basel, Switzerland: Birkhäuser; 2009:155-180.

154. Lee HM, Mima T, Sugino H, et al. Interactions among type I and type II interferon, tumor necrosis factor, and $\beta$-estradiol in the regulation of immune response-related gene expressions in systemic lupus erythematosus. Arthritis Res Ther. 2009;11(1):R1.

155. Lee EY, Lee ZH, Song YW. CXCL10 and autoimmune diseases. Autoimmun Rev. 2009;8(5):379-383.

156. Sweeney SE, Kimbler TB, Firestein GS. Synoviocyte innate immune responses. II. Pivotal role of IFN regulatory factor 3. J Immunol. 2010;184(12):7162-7168.

157. Österlund PI, Pietilä TE, Veckman V, Kotenko SV, Julkunen I. IFN regulatory factor family members differentially regulate the expression of type III IFN (IFN- $\lambda$ ) genes. J Immunol. 2007;179(6):3434-3442.

158. Kotenko SV, Pestka S. Jak-Stat signal transduction pathway through the eyes of cytokine class II receptor complexes. Oncogene. 2000;19(21):2557-2565.

159. Williams L, Bradley L, Smith A, Foxwell B. Signal transducer and activator of transcription 3 is the dominant mediator of anti-inflammatory effects of IL-10 in human macrophages. J Immunol. 2004;172(1): $567-576$

160. Wang M, Liang P. Interleukin-24 and its receptors. Immunology. 2005;114(2):166-170.

161. Trivella DB, Ferreira-Júnior JR, Dumoutier L, Renauld JC, Polikarpov I. Structure and function of interleukin-22 and other members of the interleukin-10 family. Cell Mol Life Sci. 2010;67(17):2909-2935.

162. Wolk K, Witte E, Witte K, Warszawska K, Sabat R. Biology of interleukin-22. Semin Immunopathol. 2010;32(1):17-31.

163. Szabo SJ, Sullivan BM, Peng SL, Glimcher LH. Molecular mechanisms regulating Th1 immune responses. Annu Rev Immunol. 2003;21:713-758.

164. Mowen KA, Glimcher LM. Signaling pathways in Th2 development. Immunol Rev. 2004;202:203-222.

165. Ansel KM, Djuretic I, Tanasa B, Rao A. Regulation of Th2 differentiation and IL4 locus susceptibility. Annu Rev Immunol. 2006;24: 607-656.

166. Ivanov II, McKenzie BS, Zhou L, et al. The orphan nuclear receptor ROR $\gamma \mathrm{t}$ directs the differentiation program of proinflammatory IL-17 T helper cells. Cell. 2006;126(6):1121-1133.

167. Nakayama T, Kimura MY. Memory Th1/Th2 cell generation controlled by Schnurri-2. In: Zanetti M, Schoenberger SP, editors. Memory $T$ Cells. New York, NY: Springer Science; 2010:1-9.

168. Hermann J, Gruber S, Neufeld JB, et al. IL10R1 loss-of-function alleles in rheumatoid arthritis and systemic lupus erythematosus. Clin Exp Rheumatol. 2009;27(4):603-608.

169. Riley JK, Takeda K, Akira S, Schreiber RD. Interleukin-10 receptor signaling through the JAK-STAT pathway. Requirement for two distinct receptor-derived signals for anti-inflammatory action. $J$ Biol Chem. 1999;274(23):16513-16521.

170. Ahmed ST, Ivashkiv LB. Inhibition of IL-6 and IL-10 signaling and Stat activation by inflammatory and stress pathways. J Immunol. 2000; 165(9):5227-5237.

171. Herrero C, Hu X, Li WP, et al. Reprogramming of IL-10 activity and signaling by IFN- $\gamma$. J Immunol. 2003;171(10):5034-5041.

172. Ji JD, Tassiulas I, Park-Min KH, et al. Inhibition of interleukin 10 signaling after $\mathrm{Fc}$ receptor ligation and during rheumatoid arthritis J Exp Med. 2003;197(11):1573-1583.

173. van Roon J, Wijngaarden S, Lafeber FP, Damen C, van de Winkel J, Bijlsma JW. Interleukin 10 treatment of patients with rheumatoid arthritis enhances $\mathrm{Fc} \gamma$ receptor expression on monocytes and responsiveness to immune complex stimulation. J Rheumatol. 2003;30(4): 648-651.

174. Kalliolias GD, Ivashkiv LB. IL-27 activates human monocytes via STAT1 and suppresses IL-10 production but the inflammatory functions of IL-27 are abrogated by TLRs and p38. J Immunol. 2008;180(9):6325-6333. 
175. Shahrara S, Huang Q, Mandelin AM 2nd, Pope RM. TH-17 cells in rheumatoid arthritis. Arthritis Res Ther. 2008;10(4):R93.

176. Kelly-Welch AE, Hanson EM, Boothby MR, Keegan AD. Interleukin-4 and interleukin-13 signaling connection maps. Science. 2003;300(5625):1527-1528.

177. Ratthé C, Pelletier M, Chiasson S, Girard D. Molecular mechanisms involved in interleukin-4-induced human neutrophils: expression and regulation of suppressor of cytokine signaling. J Leukoc Biol. 2007;81(5):1287-1296.

178. Wang IM, Lin H, Goldman SJ, Kobayashi M. STAT-1 is activated by IL-4 and IL-13 in multiple cell types. Mol Immunol. 2004;41(9): 873-884.

179. Morita Y, Yamamura M, Kawashima M, et al. Differential in vitro effects of IL-4, IL-10, and IL-13 on proinflammatory cytokine production and fibroblast proliferation in rheumatoid synovium. Rheumatol Int. 2001;20(2):49-54.

180. Woods JM, Katschke KJ, Volin MV, et al. IL-4 adenoviral gene therapy reduces inflammation, proinflammatory cytokines, vascularization, and bony destruction in rat adjuvant-induced arthritis. J Immunol. 2001;166(2):1214-1222.

181. Nabbe KC, van Lent PL, Holthuysen AE, et al. Local IL-13 gene transfer prior to immune-complex arthritis inhibits chondrocyte death and matrix metalloproteinase-mediated cartilage matrix degradation despite enhanced joint inflammation. Arthritis Res Ther. 2005;7(2):R392-R401.

182. Relic B, Guicheux J, Mezin F, et al. IL-4 and IL-13, but not IL-10, protect human synoviocytes from apoptosis. J Immunol. 2001;166(4): $2775-2782$.

183. Tokayer A, Carsons SE, Chokshi B, Santiago-Schwarz F. High levels of interleukin-13 in rheumatoid arthritis sera are modulated by tumor necrosis factor antagonist therapy: association with dendritic cell growth activity. J Rheumatol. 2002;29(3):454-461.

184. Woo KM, Kim HM, Ko JS. Macrophage colony-stimulating factor promotes the survival of osteoclast precursors by up-regulating Bcl-X(L). Exp Mol Med. 2002;34(5):340-346.

185. Rumore-Maton B, Elf J, Belkin N, et al. M-CSF and GM-CSF regulation of STAT5 activation and DNA binding in myeloid cell differentiation is disrupted in nonobese diabetic mice. Clin Dev Immunol. 2008;2008:769795.

186. Haas CS, Amin MA, Allen BB, et al. Inhibition of angiogenesis by interleukin-4 therapy in rat adjuvant-induced arthritis. Arthritis Rheum. 2006;54(8):2402-2414.

187. Haas CS, Amin MA, Ruth JH, et al. In vivo inhibition of angiogenesis by interleukin-13 gene therapy in a rat model of rheumatoid arthritis. Arthritis Rheum. 2007;56(8):2535-2548.

188. Ruth JH, Haas CS, Park CC, et al. CXCL16-mediated cell recruitment to rheumatoid arthritis synovial tissue and murine lymph nodes is dependent on the MAPK pathway. Arthritis Rheum. 2006;54(3): 765-778.

189. Thornton AM. Signal transduction in $\mathrm{CD}^{+} \mathrm{CD} 25^{+}$regulatory $\mathrm{T}$ cells: CD25 and IL-2. Front Biosci. 2006;11:921-927.

190. Lin JX, Leonard WJ. The role of Stat5a and Stat5b in signaling by IL-2 family cytokines. Oncogene. 2000;19(21):2566-2576.

191. Murawski MR, Litherland SA, Clare-Salzler MJ, Davoodi-Semiromi A. Upregulation of Foxp3 expression in mouse and human Treg is IL-2/ STAT5 dependent: implications for the NOD STAT5B mutation in diabetes pathogenesis. Ann N Y Acad Sci. 2006;1079:198-204.

192. Taylor DK, Walsh PT, LaRossa DF, et al. Constitutive activation of STAT5 supersedes the requirement for cytokine and TCR engagement of $\mathrm{CD}^{+}$cells in steady-state homeostasis. J Immunol. 2006;177(4):2216-2223

193. Franceschini D, Paroli M, Francavilla V, et al. PD-L1 negatively regulates $\mathrm{CD}_{4}{ }^{+} \mathrm{CD} 25^{+} \mathrm{Foxp}^{+}$Tregs by limiting STAT-5 phosphorylation in patients chronically infected with $\mathrm{HCV}$. J Clin Invest. 2009;119(3):551-564.

194. Streitholt S, Maurer B, Peters MA, Pap T, Gay S. Epigenetic modifications in rheumatoid arthritis. Arthritis Res Ther. 2008;10(5):219.
195. Karouzakis E, Gay RE, Gay S, Neidhart M. Epigenetic control in rheumatoid arthritis synovial fibroblasts. Nat Rev Rheumatol. 2009;5(5):266-272.

196. Brooks WH, Le Dantec C, Pers JO, Youinou P, Renaudineau Y. Epigenetics and autoimmunity. J Autoimmun. 2010;34(3): J207-J219.

197. Li WX. Canonical and non-canonical JAK-STAT signaling. Trends Cell Biol. 2008;18(11):545-551.

198. Shin HJ, Park HY, Jeong SJ, et al. STAT4 expression in human T cells is regulated by DNA methylation but not by promoter polymorphism. J Immunol. 2005;175(11):7143-7150.

199. Kim EG, Shin HJ, Lee CG, et al. DNA methylation and not allelic variation regulates STAT6 expression in human T cells. Clin Exp Med. 2010;10(3):143-152.

200. Shi S, Calhoun HC, Xia F, Li J, Le L, Li WX. JAK signaling globally counteracts heterochromatin gene silencing. Nat Genet. 2006; 38(9):1071-1076.

201. Nile CJ, Read AC, Akil M, Duff GW, Wilson AG. Methylation status of a single $\mathrm{CpG}$ site in the IL6 promoter is related to IL6 messenger RNA levels and rheumatoid arthritis. Arthritis Rheum. 2008;58(9): 2686-2693.

202. van den Berg WB, Miossec P. IL-17 as a future therapeutic target for rheumatoid arthritis. Nat Rev Rheumatol. 2009;5(10): $549-553$.

203. Genovese MC, van den Bosch F, Roberson SA, et al. LY2439821, a humanized anti-interleukin-17 monoclonal antibody, in the treatment of patients with rheumatoid arthritis: a phase I randomized, doubleblind, placebo-controlled, proof-of-concept study. Arthritis Rheum. 2010;62(4):929-939.

204. Ding C, Xu J, Li J. ABT-874, a fully human monoclonal anti-IL-12/ IL-23 antibody for the potential treatment of autoimmune diseases. Curr Opin Investig Drugs. 2008;9(5):515-522.

205. Lima XT, Abuabara K, Kimball AB, Lima HC. Briakinumab. Expert Opin Biol Ther. 2009;9(8):1107-1113.

206. Elliott M, Benson J, Blank M, et al. Ustekinumab: lessons learned from targeting interleukin-12/23p40 in immune-mediated diseases. Ann N Y Acad Sci. 2009;1182:97-110.

207. Hartgring SAY, van Roon JAG, Wijk MWV, et al. Elevated expression of interleukin-7 receptor in inflamed joints mediates interleukin-7induced immune activation in rheumatoid arthritis. Arthritis Rheum. 2009;60(9):2595-2605.

208. Harry RA, Anderson AE, Isaacs JD, Hilkens CM. Generation and characterisation of therapeutic tolerogenic dendritic cells for rheumatoid arthritis. Ann Rheum Dis. 2010 Jun 15. [Epub ahead of print] PMID: 20551157.

209. O'Shea JJ, Pesu M, Borie DC, Changelian PS. A new modality for immunosuppression: targeting the JAK/STAT pathway. Nat Rev Drug Discov. 2004;3(7):555-564.

210. Feely MG. New and emerging therapies for the treatment of rheumatoid arthritis. Open Access Rheumatol Res Rev. 2010;2:35-43.

211. Kremer JM, Bloom BJ, Breedveld FC, et al. The safety and efficacy of a JAK inhibitor in patients with active rheumatoid arthritis: results of a double-blind, placebo-controlled phase IIa trial of three dosage levels of CP690,550 versus placebo. Arthritis Rheum. 2009;60(7):1895-1905.

212. Coombs JH, Bloom BJ, Breedveld FC, et al. Improved pain, physical functioning and health status in patients with rheumatoid arthritis treated with CP690,550, an orally active Janus kinase (JAK) inhibitor: results from a randomised, double-blind, placebo-controlled trial. Ann Rheum Dis. 2010;69(2):413-416.

213. Kim BH, Oh SR, Yin CH, et al. MS-1020 is a novel small molecule that selectively inhibits JAK3 activity. Br J Haematol. 2010;148(1): 132-143.

214. Quintás-Cardama A, Vaddi K, Liu P, et al. Preclinical characterization of the selective JAK1/JAK2 inhibitor ICNB018424: therapeutic implications for the treatment of myeloproliferative neoplasms. Blood. 2010;115(15):3109-3117. 
215. Fridman JS, Scherle PA, Collins R, et al. Selective inhibition of JAK1 and JAK2 is efficacious in rodent models of arthritis: preclinical characterization of INCB028050. J Immunol. 2010;184(9):5298-5307.

216. Messerschmitt PJ, Rettew AN, Brookover RE, Garcia RM, Getty PJ, Greenfield EM. Specific tyrosine kinase inhibitors regulate human osteosarcoma cells in vitro. Clin Orthop Relat Res. 2008;466(9):2168-2175.

217. Tyner JW, Bumm TG, Deininger J, et al. CYT387, a novel JAK2 inhibitor, induces hematologic responses and normalizes inflammatory cytokines in murine myeloproliferative neoplasms. Blood. 2010;115(25):5232-5240.

218. Wernig G, Kharas MG, Okabe R, et al. Efficacy of TG101348, a selective JAK2 inhibitor, in treatment of a murine model of JAK2V617Finduced polycythemia vera. Cancer Cell. 2008;13(4):311-320.

219. Geron I, Abrahamsson AE, Barroga CF, et al. Selective inhibition of JAK2-driven erythroid differentiation of polycythemia vera progenitors. Cancer Cell. 2008;13(4):321-330.

220. Sun J, Blaskovich MA, Jove R, et al. Cucurbitacin Q: a selective STAT3 activation inhibitor with potent antitumor activity. Oncogene 2005;24(20): 3236-3245.
221. Horiguchi A, Asano T, Kuroda K, et al. STAT3 inhibitor WP1066 as a novel therapeutic agent for renal cell carcinoma. Br J Cancer. 2010;102(11):1592-1599.

222. Zhang L, Alizadeh D, van Handel M, Kortylewski M, Yu H, Badie B. Stat3 inhibition activates tumor macrophages and abrogates glioma growth in mice. Glia. 2009;57(13):1458-1467.

223. Spagnoli A, Torello M, Nagalla SR, et al. Identification of STAT-1 as a molecular target of IGFBP-3 in the process of chondrogenesis. J Biol Chem. 2002;277(21):18860-18867.

224. Shipley JM, Waxman DJ. Down-regulation of STAT5b transcriptional activity by ligand-activated peroxisome proliferator-activated receptor (PPAR) $\alpha$ and PPAR $\gamma$. Mol Pharmacol. 2003;64(2):355-364.

225. Böhm C, Hayer S, Kilian A, et al. The $\alpha$-isoform of p38 kinase MAPK specifically regulates arthritic bone loss. J Immunol. 2009;183(9): $5938-5947$.

226. Genovese MC. Inhibition of p38: has the fat lady sung? Arthritis Rheum. 2009;60(2):317-320.

227. Hammaker D, Firestein GS. "Go upstream, young man": lessons learned from the p38 saga. Ann Rheum Dis. 2010;69 Suppl 1:i77-i82.

International Journal of Interferon, Cytokine and Mediator Research

\section{Publish your work in this journal}

The International Journal of Interferon, Cytokine and Mediator Research is an international, peer-reviewed, open-access, online journal. The focus of the journal is to publish original research, reports, editorials, reviews and commentaries on all aspects of interferon, cytokine and mediators of inflammation from labora- tory science to therapeutic indications and clinical studies. The manuscript management system is completely online and includes a very quick and fair peer-review system, which is all easy to use. Visit http://www.dovepress.com/testimonials.php to read real quotes from published authors.

Submit your manuscript here: http://www.dovepress.com/international-journal-of-interferon-cytokine-and-mediator-research-journal 